\title{
RECORDANDO A INFÂNCIA DO MARKETING BRASILEIRO - UM DEPOIMENTO
}

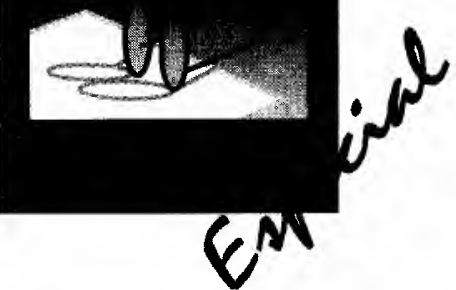

* Raimar Richers

A relação do marketing no Brasil com a economia, política e ambiente social.

The relationship among Brazilian marketing and economy, politics and social environment.

PalaVRa-ChaVE:

História e conceito de marketing, consumo, consumidor.

\section{KEY WORDS:}

Marketing history and concept, consumption, consumer.
Pediram-me que escrevesse sobre a história do Marketing no Brasil. Hesitei muito, pois me pergunto: "Será que uma disciplina pode alegar história com apenas 40 anos? E mesmo que a tenha, temos distância suficiente para poder descrevê-la?" Mas insistiram e, finalmente, acatei.

Dividi o artigo em duas partes: uma inicial, que são "memórias" em torno dos primeiros anos da EAESP e a outra, que procura dar uma visão de conjunto dos primeiros 40 anos de Marketing no Brasil.

* Professor Fundador do Departamento de Mercadologia da EAESP/FGV. 


\section{OS PRIMEIROS PASSOS DA EAESP}

O Marketing, no Brasil, nasceu numa época muito oportuna: nos dourados anos 50 . Muitos de vocês não devem se lembrar dessa, época, mas asseguro-lhes que o Brasil era um país diferente: bem mais simples, com pouco trânşito e praticamente sem assaltos, nem poluição. As mercadorias eram poucas e as lojas também; uma parcela substancial da populaçăo vivia de produtos agrícolas e havia bem menos consumidores. Acima de tudo, era um mundo bem mais feliz. Todos se divertiam, dançando com as músicas de Harry James e Ray Coniff, que embalavam os bailes de formatura. Judy Garland cantava "Over the rainbow" e as paredes dos quartos femininos estavam repletas de fotos de Marlon Brando e do novo herói James Dean. O bambolê girava nas cinturinhas de vespa das cocadinhas que começavam a preparar-se para a explosảo do rock e para receber o seu grande ídolo imortal Elvis Presley. Bebia-se rum com CocaCola em danceterias agitadas; as meninas com vestidos de nylon

bem comportados, os meninos com seus topetes com brilhantina. As moças não tinham direito de fazer per-
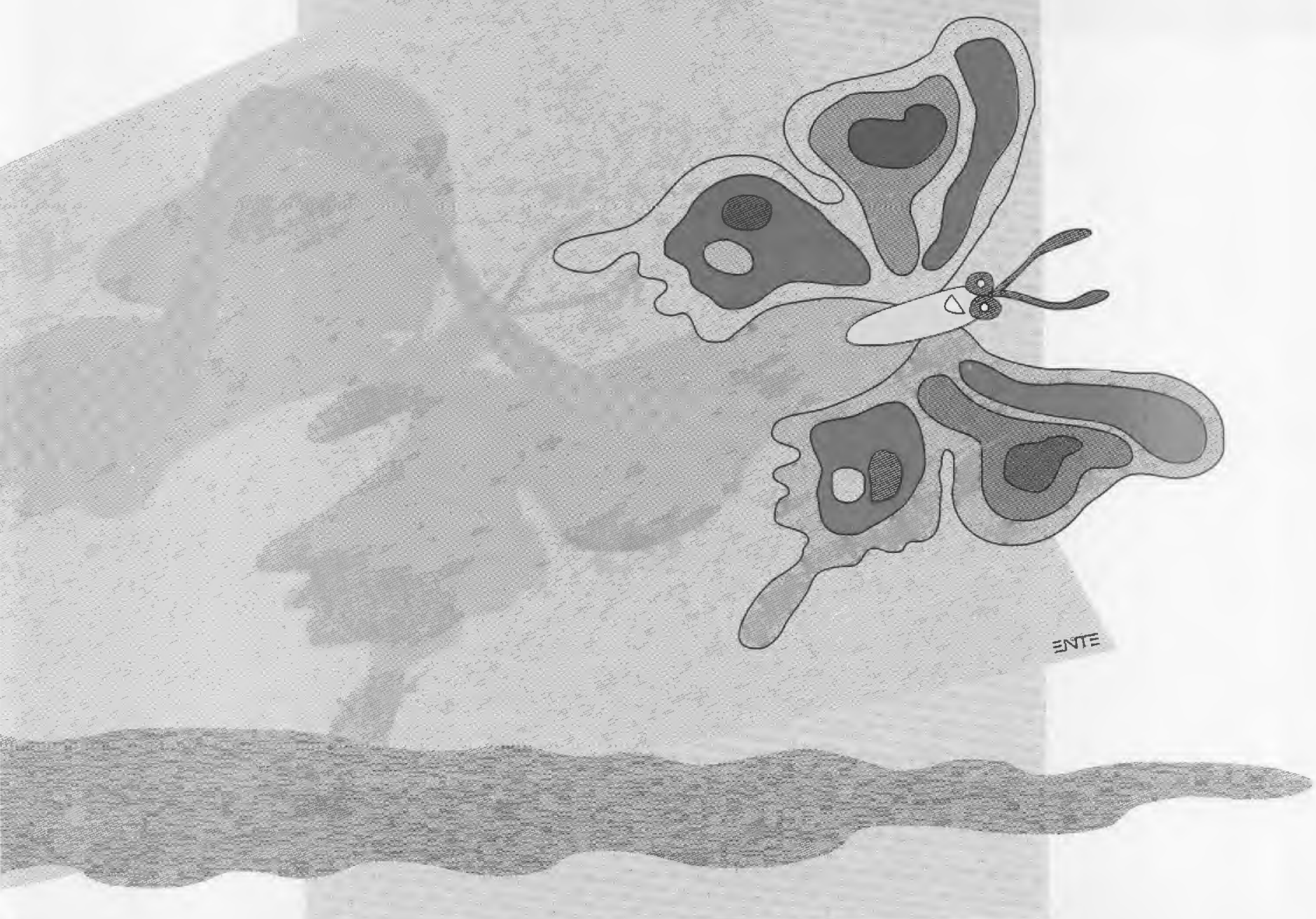
guntas, simplesmente aceitavam os dogmas "normais"; eram evidentemente virgens e assumiam que os homens tivessem experiências antes do casamento, mas não a mulher.

Não por acaso chamava-se esta época de Anos Dourados. Eles nunca mais se repetiram. É que, além da música, do esporte, da primeira Bienal, dos carnavais de rua, havia sobretudo esperança e a sensação de que o país estava

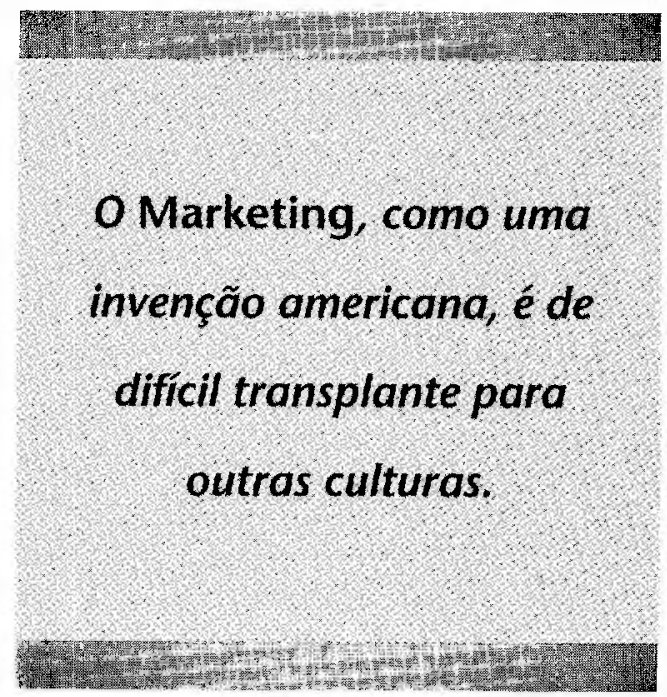
indo para frente e que isto sempre seria assim. Era o grande movimento da libertação mundial, regado a champanhe e festejado com músicas populares: o jazz negro nos EUA e a bossa-nova no Brasil, com Tom Jobim, Vinícius de Morais e João Gilberto. A Europa estava se recuperando de suas profundas feridas da guerra sangrenta. A África se descolonizava aos poucos e, na Ásia, vários países preparavam-se para seu papel de tigres.

Foi neste ambiente de euforia que alguém na Fundação Getúlio Vargas, no Rio de Janeiro, teve uma idéia brilhante: criar uma faculdade de Administração de Empresas e na cidade onde a industrialização estava começando a se manifestar: São Paulo. Não sei se foram os autores da idéia, mas certamente o comandante Tornaghi e o professor Luís Alves de Mattos abraçaram a idéia e a levaram para frente. Mas não havia recursos materiais, nem humanos com experiência suficiente para transformar o plano em realidade. Estabeleceuse então um contato com o governo americano para apoiar a idéia que, naquela época, vinha ao encontro dos próprios objetivos do chamado Ponto IV, que visava a dar apoio aos países em desenvolvimento, a partir da experiência brilhantemente concebida e muito bem-sucedida do Plano Marshall na Europa. Fezse então um acordo com uma universidade americana, a Michigan State University, para instituir a Escola de Administração de Empresas num dos andares de um prédio, cedido pela Delegacia Regional do Trabalho, na Rua Martins Fontes, em São Paulo. Realizou-se primeiro um concurso para assistentes e convidou-se quatro professores americanos para integrarem a primeira missão. E assim começou a FGV/SP, de maneira muito modesta, mas com grande expectativa e entusiasmo.

A missão americana era chefiada por um professor muito firme e dedicado à sua tarefa. Ele nos fez sofrer - seus oito assistentes jovens e impetuosos - porque a sua visão didática era exatamente o oposto daquilo que nós achávamos que seria adequado para o país. Estávamos impregnados do sistema tradicional, da palavra ex-cathedra do professor que fala aos seus alunos à semelhança de um pastor que se dirige às "suas ovelhas": com voz grave e segura, imbuído de conhecimentos que seus humildes receptores aceitavam como fatos. Não era esta a visão do professor Karl Boedecker. Para ele, o método de ensino deveria ser participativo, onde o professor é, acima de tudo, um moderador: coloca uma noção, talvez até uma dúvida, a uma platéia 
de seres inteligentes e preparados a dissecá-la de todos os seus lados objetivos e subjetivos. Para nós, isto era uma heresia: como se pode dar tanta liberdade a um público leigo? Como se pode permitir o livre debate entre um professor preparado e a massa de alunos inexperientes? Levou anos, mas a mensagem do professor Boedecker tornou-se vencedora e hoje muitos de nós didatas reconhecemos: só se aprende quando há envolvimento e participação de quem estuda.

\section{MARKETING: UMA INSTITUIÇÃO AMERICANA}

O que tem isto a ver com o Marketing? É que os quatro professores da missão americana compartilhavam essa filosofia, na época revolucionária, até nos EUA. Entre eles estava o primeiro professor de Marketing a lecionar no Brasil. Seu nome era Ole Johnson. É dele que ouvi, pela primeira vez na minha vida, a palavra Marketing, o que é estranho, pois não era novato na área acadêmica e já tinha recebido o meu doutorado em Economia por uma universidade suiça. Mas, naquela época, o Marketing era uma novidade no mundo todo - menos nos EUA, onde já era praticado há alguns decênios.

Isto vem demonstrar que o Marketing, como uma invenção americana, é de difícil transplante para outras culturas, sejam elas do Primeiro ou do Terceiro Mundo. Falta-nos aquela atitude que, em parte por intuição, em parte por herança, coloca o consumidor sempre em primeiro lugar e sempre se esforça para adaptar a sua oferta ao gosto prevalecente do mercado. Não que não se pratique o Marketing em países como o nosso, ou no Japão ou na Europa. Mas aquela naturalidade com que o americano conjuga produto com marca, marca com preço, preço com distribuição, distribuição com força de vendas, força de vendas com publicidade e mistura tudo isto num grande caldeirão que se oferece ao consumidor (com um sorriso) é um dom que o americano já parece trazer nos genes.

Confesso que, no início, achava isto tolice. Quando fiz a minha primeira viagem (como bolsista) aos EUA, estava firmemente decidido a não me dedicar ao Marketing. Mas era obrigado a tomar pelo menos algumas aulas e foi nelas que mudei de idéia, nas mãos de professores como Tom Staudt e Donald Taylor, titulares da M.S.U. Comecei a compreender a complexa engrenagem que é o Marketing quando aplicado a uma economia competitiva. Compreendi também por que o Marketing é essencial para que uma empresa possa ser bem-sucedida no mercado, e que a afirmação lapidar e simples de que "o consumidor é rei" tem significados muito diferenciados, dependendo do produto que você representa e do mercado que você quer conquistar.

\section{OS 4 PS E OS 4 AS}

De volta ao Brasil, estávamos ansiosos para transmitir as novas idéias aos executivos brasileiros. Mas havia um impedimento: o nome da matéria, que teria que ser traduzido, porque na sua forma original, jamais seria aceito pelo executivo brasileiro. Era preciso abrasileirá-lo e nós o abrasileiramos, não evidente- 
mente sem longos e ferrenhos debates. Mas, no fim, anunciamos que a expressão correta para a nova "ciência" seria Mercadologia e o processo de distribuição que a caracterizasse teria que ser chamado Mercadização.

Mas o mercado não aceitou... e nos deu uma lição inesquecível sobre o uso da marca. O nome era aquele mesmo: simplesmente Marketing. Não havia outro. Apenas ficou um resquício de nossa tentativa desesperada de abrasileirar um nome intraduzível. De vez em quando fala-se de mercadólogos, porque é complicado referir-se ao executivo de Marketing de outra maneira, enquanto que a palavra mercadizar também ficou (meio na sombra), em substituição à expressão anglo-saxônica do "to market" - levar algo ao mercado para lá vendê-lo.

Definida a palavra, faltava o conceito. No meu entender, os livros-texto americanos não expressavam bem o que as empresas praticavam quando adotavam o Marketing como sua filosofia. Explicavam, em parte com surpreendente precisão e clareza, as diversas funções do Marketing, mas deixavam de mostrar como se integravam dentro de uma visão sistêmica e voltada a um determinado objetivo.

Só houve uma tentativa neste sentido que é do professor Jerome McCarthy e que, ao longo dos anos, se difundiu no mundo inteiro. Refiro-me aos 4Ps, que representam uma mancira simples e lapidar de não só resumir, como também mostrar a interdependência das principais funções mercadológicas. Todavia, por mais didático que fosse, mesmo este conceito me parecia estreito, por abranger apenas uma parte das funções, e sobretudo por não transmitir a posição do Marketing dentro da empresa e da sua relação (fundamental) para com o meio ambiente. Achava, portanto, oportuno criar um novo conceito, mais abrangente e necessariamente sistêmico.

Foram os 4As, cuja principal preocupação está cm estabelecer dois tipos de elos: de um lado, o do Marketing com a empresa e seus objetivos estratégicos; do outro, da empresa para com o mercado e a sua melhor maneira para atingir esses objetivos. Isto requer uma investigação cautelosa das forças de mercado e da estimativa do seu potencial e tamanho (Análise, o primeiro dos 4As); a adequação da linha de produtos aos desejos dos consumidores através da aplicação de instrumentos como o design, o preço, a marca e a prestação de serviços (Adaptação); a colocação dos produtos no momento e no lugar certo para que o consumidor os tenha sempre presentes, o que envolve a distribuição, a logística, a força de vendas e a publicidade (Ativação) e, finalmente, a obrigação de acompanhar este processo continuamente para eliminar erros, aumentar a eficácia e estimular o retorno sobre os investimentos (Avaliação).

Como cra de se esperar, os 4As não criaram muito impacto na EAESP - Escola de Administração de Empresas de São Paulo - mas isto pouco importa, pois abraçamos todos o mesmo princípio no departamento de Marketing. Ele é uma herança da escola americana, o que nos dá uma integridade de conceituação, além de uma linguagem comum que nos une.

Marketing, para nós, é um conjunto de funçōes integradas. Isto vale tanto para os professores da vanguarda - como Gusta- 
vo de Sá e Silva, Pólia Lerner Hamburger, Orlando Figueiredo, Affonso Arantes e Bruno Guerreiro -, como também para a maioria dos que nos seguiram na carreira de professor. Para nós, não havia outro Marketing a não ser estè, e ao longo dos primeiros anos de existência da EAESP, fomos inconscientemente apoiados por alguns professores americanos que continuavam a lecionar na Escola, tais como Donald Taylor, Leo Erickson e Dole Anderson. Com o último, montamos o Centro de Pesquisa e Publicações da EAESP, que lançou o primeiro número da RAE - Revista de Administração de Empresas e cujo produto de maior peso (tanto no sentido figurativo quanto físico) foi o primeiro livro-texto na área de Marketing publicado no Brasil. Seu nome é Administração Mercadológica: princípios e métodos. Nele colaboraram os oito professores de Marketing mais antigos da instituição. A sua primeira edição se deú no ano de 1972, e mesmo hoje, mais de vinte anos depois, o livro - ao qual os alunos se referem. causticamente como "tijolão" - é usado em várias inistituiçōes de ensino de Administração no Brașil.

\section{UM QUADRO GERAL PARA O MARKETING}

O Marketing integrado só faz sentido desde que seja encarado como uma parte da engrenagem econômica e social de uma nação. Para ilustrar como o Marketing se relaciona com as áreas macro - tais como a economia, a política e o ambiente social - a tabela 1 apresenta oito itens, dos quais apenas os dois últimos referem-se diretamente à nossa matéria. Os outros lidam com o ambiente macro e todos eles (com exceção do primeiro) constituem uma interpretação do cenário em que a empresa, de um lado, e o consumidor, do outro, se movimentam. A interpretação desse quadro é sumária e "histórica", procurando focalizar apenas as tendências, sob os seguintes enfoques:

1. Os presidentes - Durante a maior parte do período considerado, - Brasil era uma ditadura. Mas, para todos os efeitos históricos, só pode ter sido uma ditadura branda, pois nenhum dos presidentes permaneceu mais do que cinco anos no governo. Até o mais "rude" deles, o general Figueiredo, sancionou a Lei da Anistia, que perdoava os crimes cometidos pelos guerrilheiros e as forças de repressão. Exilados voltavam em massa e presos políticos eram soltos. O presidente, na época, avisou aos descontentes com a lei: "É para abrir mesmo, e quem não quiser que eu abra, eu prendo e arrebento".

2. Tendências econômicas e políticas - Ao longo dos 40 anos, tivemos apenas duas épocas positivas: uma no inúcio, quando o presidente Kubitschek promoveu a industrialização, e mais tarde (de 1969-73) durante o "milagre econômico". Os outros anos apontam basicamente para baixo, com um endividamento exterruo crescente, um orçamento quase sempre em déficit, juros reais ascendentes e um ônus fiscal que, em 1991, chegava a 75\% do PIB - Produto Interno Bruto. Vem-nos à mente a famosa expressão de De Gaulle: "Este näo é um país sério". Será que ele estava se referindo ao governo, ou ao povo como um todo? 
Tabela 1: 0 CONTEXTO DO MARKETING NA EVOLUÇÃO POLITICO-ECONÔMICA DO BRASIL

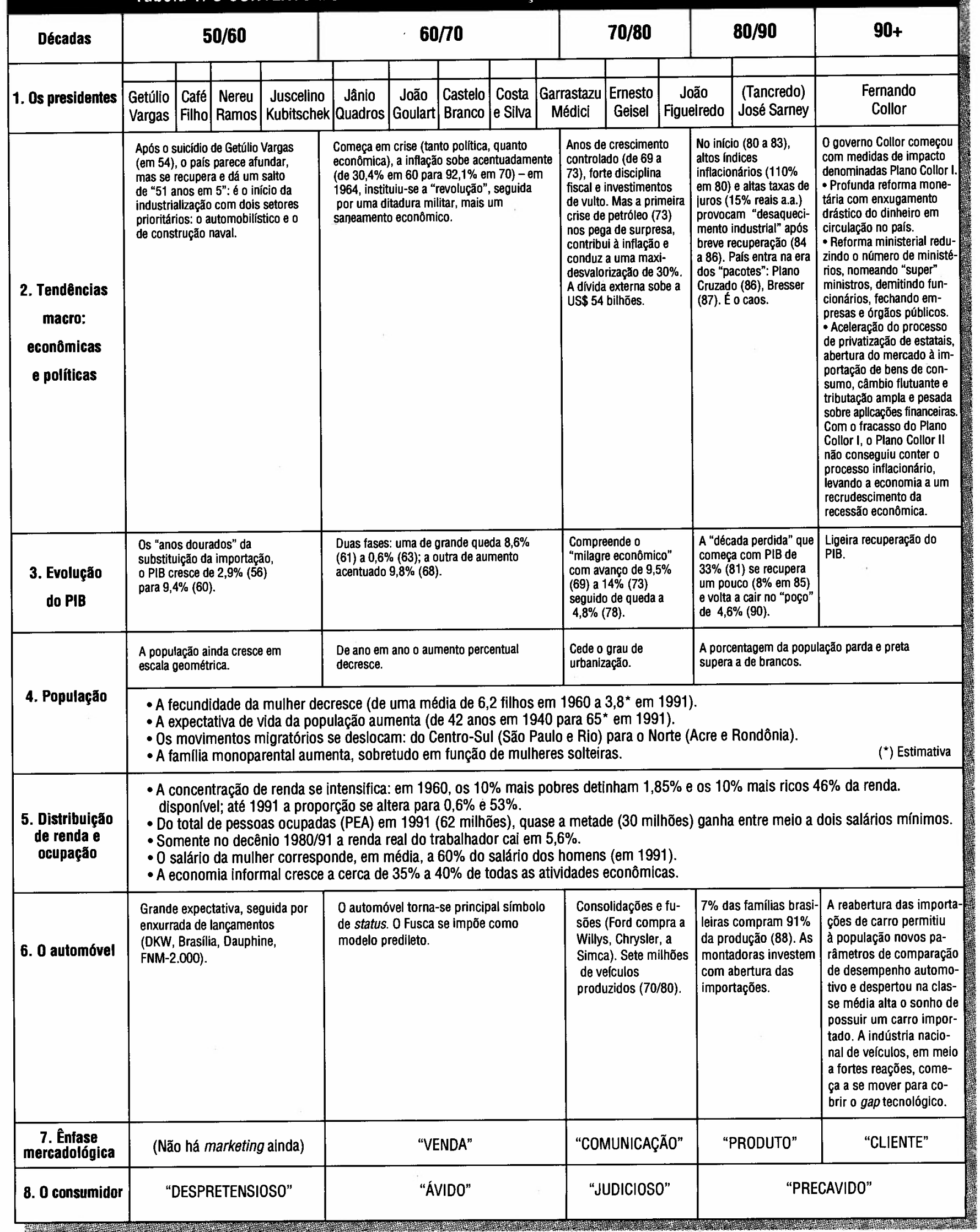


3. Evolução do PIB - Tendo em vista a pândega política e econômica que caracteriza o país, o PIB evolui razoavelmente. Houve épocas em que ele caiu assustadoramente (sobretudo nos anos 81 e 83), mas, na maioria dos anos, comportou-se de maneira bastante favorável. Em média, movimentou-se entre $5 \%$ e $10 \%$ a.a., um indício de que o Brasil tem um dinamismo inerente que mesmo a incompetência mais dramática não consegue sufocar.

4. População - O governo lava as mãos: para ele, o problema demográfico não é de sua alçada, mas também não gosta que instituições privadas exerçam a função do planejamento familiar. Assim, a população age sozinha: reduz a taxa de crescimento anual de $4 \%$ (em 1940), a 2,8\% (?) (em 1991). Ao mesmo tempo, a fecundidade da mulher decresce e aumenta a expectativa de vida da população. São sinais favoráveis num país onde o Governo é notoriamente indiferente aos problemas sociais.

5. Ocupação e distribuição de renda - É talvez o capítulo mais triste de nossa história. Toda a concentração de renda vai para os mais ricos; os mais pobres que subsistam sozinhos. A força de trabalho aumenta e uma parte considerável não encontra emprego, sobretudo a enorme massa de pessoas desqualificadas. Como é que ela sobrevive? Juntando os membros da família para formar uma mini-cooperativa ou ingressando nas fileiras da economia informal.

6. Automóveis - Incluímos este bem de consumo como representativo para a nação. Foi com ele que iniciamos o nosso processo de industrialização nos anos 50 . As montadoras absorveram e treinaram um número considerável de empregados e provocaram a criação de incontáveis empresas de fornecimento. $O$ automóvel é um símbolo de status que o rico expõe, o meio-rico se esforça por conseguir e é um sonho do pobre. Atualmente, com a onda eufórica dos carros em declínio, só se consegue reativála importando, para obrigar as montadoras a investirem e a racionalizarem. $O$ nosso alvo deve ser: transformar o Brasil num dos principais fornecedores mundiais de automóveis no processo de globalização.

7. Ênfase mercadológica - Aproveito uma tese que o nosso ex-aluno Aderson Lopes ${ }^{1}$ apresentou no evento "Marketing Brasil" de 1982. Argumenta o Aderson que cada um dos três decênios inicia as suas atividades de Marketing com um viés - o de $60 \mathrm{com}$ "vendas", o de 70 com "propaganda", o de 80 com "produtos". Ele não só defendeu a sua tese com bastante habilidade, como nos ofereceu uma perspectiva histórica digna de avaliação. A última fase, "mercados", ainda não faz parte de sua tese, mas é importante incluí-la, o que é feito a seguir.

8. O consumidor - Não sem alguma arbitrariedade procuro caracterizar a evolução do nosso consumidor de "despretensioso" a "precavido", a fim de marcar etapas razoavelmente bem acentuadas de seu caminho tortuoso. Cada uma dessas etapas é caracterizada por alguns comportamentos típicos, a partir dos quais o produtor e o distribuidor programam as suas atividades.
1. LOPES, Aderson Alves. As três fases do Marketing brasileiro. Marketing Brasil. Evento do RRCA - Raimar Richers Consultores Associados, maio 1982. . Proposta de modelo alternativo à teoria da utilidade. São Paulo: EAESP/FGV, 1977 (dissertação de mestrado). 


\section{Quadro 1: 0 MERCADO ATÉ A DÉCADA DE 50}

- É concentrado na faixa litorânea (80\%) - o interior "dorme"; há dois Brasis: 0 urbano que se moderniza e o rural que permanece "elitista".

- As atividades econômicas ainda são predominantemente primárias: $60 \%$ da população economicamente ativa trabalha no campo.

- Fortes disparidades sociais (como hoje), mas com outros acentos de liderança: classe dominante é agrícola e comercial (hoje industrial e bancária); políticos influentes são os "coronéis" (buscando manter o status quo) e os "populistas"(buscando reformas com apoio popular).

- A guerra marca a sociedade e a economia profundamente: faltam combustíveis, energia, bens industrializados em geral, mas as matérias-primas se valorizam extraordinariamente: café, algodão, cacau, minérios, mica geram balança comercial positiva.
- No pós-guerra: uma onda de importações provoca um déficit elevado do balanço de pagamentos (até ser controlada em 1953).

- 0 capital estrangeiro se interessa pelo Brasil e investe em setores modernos: automóveis, estaleiros, siderurgia etc.

- Mas a industrialização ainda é rudimentar e atende a necessidades locais: alimentos, têxteis, bebidas, construção civil etc. Muitas empresas de "fundo de quintal" e familiares.

- Os mercados são formados por nichos geográficos isolados entre si: 0 comércio é concentrado em feiras livres e no pequeno varejo.

- A intercomunicação regional é precária: estradas de ferro incipientes, rádio, aviação, sobretudo cabotagem. Poucas estradas de rodagem.

\section{DO CONSUMIDOR "DESPRETENSIOSO" AO "ÁVIDO"}

O Marketing não conquistou a alma dos brasileiros com muita facilidade e rapidez. Foi um processo lento e bastante agitado, movido por grandes ambições e muita insegurança.

Como a maioria das nações que evoluiu durante o sangrento conflito da Segunda Guerra Mundial, o Brasil do pós-guerra foi marcado por uma grande escassez de bens e uma expectativa maior ainda: faltavam produtos, mas a guerra acabara e todos esperavam a chegada dos anos dourados da paz (ver quadro 1 ). O consumidor, no entanto, era ingênuo, despreparado, inexperiente e "despretensioso". Está ciente desta sua fragilidade e olha para o exterior em busca de modelos dignos de aquisição. Como o que lhe oferecem as empresas nacionais é feito de maneira ainda precária, tende a exagerar a qualidade dos produtos estrangeiros. Não distingue entre o bom, o aceitável e o ruim: aceita tudo como de alta qualidade, contanto que tenha um made in... estampado. Mas, mesmo com respeito aos produtos nacionais, faltam-lhe critérios de comparação, o que o induz a se satisfazer com muita quinquilharia. As empresas se aproveitam desta ingenuidade e faturam mais em função da demanda desnorteada e em contínua ascensão do que de um esforço de adaptação ao mercado (ver quadro 2).

Quando o presidente Kubitschek fechou as fronteiras para anunciar a política de substituição de importações, o público vibrou: tinha chegado a hora de satisfazer os anseios consumistas com produtos industrializados modernos, de boa qualidade, a preços acessíveis.

A nova filosofia produtiva tinha um embasamento filosófico de peso: a convicção, propagada a partir da Comissão Econômica para a

\section{Quadro 2: 0 CONSUMIDOR DESPRETENSIOSO}

- É marcado pela escassez do período de guerra.

- Consome acima de tudo produtos primários: leite, feijão, arroz, mandioca, carne etc.

-É inexperiente com produtos industriais sofisticados.

- Prepara comida caseira procurando variar pratos, mas tem poucas opções.

- Joga fora os "excessos" (de alimento) que poderia aproveitar (esbanja).

- Aceita a falta de mercadorias como algo inevitável, mas que um dia mudará.
- É passivo - confia no vendedor, não regateia e dificilmente rejeita produtos.

- Aceita o preço como representando qualidade.

- Está sempre disposto a experimentar novidades.

- Não tem quase escolha entre marcas competitivas.

- Para ele, o produto importado é bom, o nacional, ruim.

- 0 efeito de demonstração de produtos estrangeiros (através de revistas e viagens) exerce forte influência sobre seus hábitos e desejos: constitui a base da formação da demanda primária de bens industriais modernos (TV, eletrodomésticos, carros, enlatados etc.). 
América Latina - encabeçada por Raul Prebisch (um grande pregador) -, de que só o protecionismo poderia salvar o subcontinente da miséria. Os campos ideológicos logo se dividiram: de um lado, os liberalistas, encabeçados pelo "entreguista" Roberto Campos, que combatiam a tese protecionista; do outro, uma enxurrada de intelectuais esquerdistas, liderados pelo radical Celso Furtado, que nela viam o endosso oficial de sua doutrina - absurda e abstrusa - de que o subdesenvolvimento do Brasil (e da América Latina em geral) devia-se à dependência de países mais avançados, como os Estados Unidos.

Juscelino, no entanto, tinha uma visão mais pragmática. Queria lançar mão de investimentos estrangeiros para dar um grande impulso ao Brasil. E conseguiu. Escolheu duas indústrias de base (automobilística e construção naval) e soube atrair capitais estrangeiros com apoio oficial de ambos os lados. Investimentos de vulto foram realizados na indústria automobilística. Envolvidas pelo entusiasmo e pela expectativa de grandes vendas, junto a um mercado amplo e virgem, as montadoras lançaram muito mais modelos de automóveis e utilitários do que o mercado era capaz de absorver. Entre eles, um se destacava: o Fusca, que tornou-se um símbolo de emancipação e bem-estar nacional.

A ordem do dia era expressa pelo slogan: "obsolescência planeja$\mathrm{da}^{\prime \prime}$. Ela ditava que as empresas inovassem continuamente e lançassem produtos novos no mercado, não importando se o consumidor tivesse se fartado com os antigos ou não. Os avanços tecnológicos da época beneficiavam muito esta tendência infatigável $e$, muitas vezes, exagerada. Surgiram a televisão em cores e a máquina de escrever eletrônica, a copiadora Xerox e o aparelho de som estereofônico e, para coroar toda esta evolução, o campeão das invenções do nosso século: o computador.

O Brasil estava ansioso em participar e usufruir desta evolução. E participou. Esqueceu-se apenas que esse tipo de política não se coaduna com o protecionismo: é preciso abrir as fronteiras para poder se beneficiar dos avanços tecnológicos que dão impulso ao mundo. Ao invés disso, radicalizamos a política de substituição de importações, inventando um monstro: a nacionalíssima reserva de mercado. Não compreendemos a tempo que o que valia para a época de Juscelino provocaria o retrocesso trinta anos mais tarde.

"Mas, em seus estágios iniciais, o protecionismo trouxe vantagens inegáveis ao país, sobretudo porque era do tipo "moderado": procurava atrair capitais do exterior e obteve com isto bastante sucesso ao longo dos anos. Surgiu um amplo e diversificado parque industrial à sua sombra e, à medida que aumentava a oferta em cada um dos setores, aumentou também a concorrência e, com ela, a preocupação com o consumidor. Surgiram marcas de peso e as empresas começaram a caprichar nas embalagens. Ao mesmo tempo, o comércio mais moderno (supermercados, os primeiros shoppings e lojas especializadas) começou a evoluir (ver quadro 3 ).

O apelo predominante para o Marketing daquela época não era do tipo integrado. Longe disto, o que se achava era que, ampliando-se o corpo de vendas e dando-lhe mais apoio, a empresa teria sucesso. $E$ várias tiveram, sobretudo aquelas que sabiam conjugar o esforço de vendas com a pesquisa de mercado. Esta ajudou a descobrir segmentos ainda pouco ou nada explorados, enquanto aquele fornecia $o$ instrumental para conquistá-los. Mas exagerou-se a dose, e, como conseqüência, muitas empresas caíram na armadilha daquilo que Aderson Lopes chama de "a falácia dos anos 60: bom vendedor vende qualquer produto". 


\section{Quadro 3: 0 CONSUMIDOR ÁVIDO}

- Procura melhorar sua qualidade de vida, em boa parte através do consumo.

- Procura o status que, inicialmente, encontra no Fusca e na TV preto-ebranco, mais tarde numa variedade de produtos com marca.

- Dá muito valor à inovação, na sua maneira de se vestir e portar, bem como nas reformas de sua casa.

- Aumenta a sua sensibilidade à mensagem publicitária televisionada.
- Começa a atribuir importância às marcas e dá maior atenção aos preços.

- Ainda vibra com o Brasil "50 anos em 5" mas sente também os reflexos de uma primeira onda de inflação acentuada ( $92 \%$ em 1964).

- Mesmo assim, o consumo lhe é mais importante que a poupança, paga prestações sem se preocupar com os juros: o importante é poder pagar as parcelas.

\section{O CONSUMIDOR “JUDICIOSO”}

Méritos à parte, o presidente Juscelino implantou dois males, dos quais ainda hoje sofremos: a inflação desenfreada e o paternalismo do Estado. Estes males apareceram no momento em que a ditadura militar enfraquecida passou a relaxar a sua política de ordem fiscal e cambial, antes rígida e disciplinada, para dar lugar a uma espécie de Éden em que os "eleitos" viviam protegidos e beneficiados por um sistema político corrupto. No início, esse sistema operava ainda de maneira clandestina, mas já começava a ruir a estabilidade econômico-financeira, conseguida antes através de muitos esforços.

Os consumidores, desde que pertencentes às classes mais elevadas, seguiam bem. As taxas inflacionárias se mantinham em níveis razoáveis, para um país em desenvolvimento, e os consumidores aprenderam a trabalhar com o seu dinheiro. Agora, antes de comprar, preparavam orçamentos familiares, utilizavam listas de compras, iam de loja em loja para comparar preços, disciplinavam os seus gastos, tornavamse mais céticos, desconfiavam do vendedor e de suas "promessas", regateavam quando achavam conveniente, usavam até máquina de calcular, começavam a entender de juros e comentavam a qualidade dos produtos e de seus preços em rodas familiares e sociais. Forma-se o consumidor brasileiro moderno, sempre essencialmente emotivo, mas já bem mais racional. É o consumidor que chamamos de "judicioso" (ver quadro 4).

Ao mesmo tempo, o Marketing também evolui e desloca o seu "centro de gravidade", na expressão de Aderson Lopes, "da infantaria da venda para a artilharia da mídia eletrônica". As empresas definem seus públicosalvo e algumas começam a pensar na segmentação como opção estratégica: existe o consumidor e ele deve ser atendido nos seus desejos espe-

\section{Quadro 4: 0 CONSUMIDOR JUDICIOSO}

- É filho da industrialização e da ascensão social na classe média.

- Abrange as três classes mais "elevadas" (A, B e C) que representam $46 \%$ da população e $98 \%$ do mercado.

- As classes D e E são cada vez mais isoladas do mercado.

- Tem melhor nível de instrução que seus pais.

- Tem poder aquisitivo (aumento real + concentração de renda).

- Recebe mais pelo seu dinheiro (para comprar TV em cores em 1980 gasta de 8 a 10 salários mínimos, mas em 1960 era no mínimo 5 vezes mais).

- É (em média) um pouco mais idoso e experimentado (devido à redução da taxa de natalidade)

- Começa a utilizar o cartão de crédito.
- Precisa ser "conquistado" pelo vendedor e através da publicidade, financiamentos, ofertas especiais, embalagens sugestivas e promoções.

- É sensivel à publicidade, mas ao mesmo tempo desconfia dela.

- Comprar é um ato social e de lazer que freqüentemente envolve a família toda.

- A mulher (mais emancipada) participa cada vez mais das decisões de compra, mas o homem (comprador mais crítico e racional) visita mais 0 supermercado.

- Tem opções de escolha (entre produtos substitutivos): mais marcas para o mesmo tipo de bem, mais pontos de venda, mais alternativas de tamanhos, acessórios, modelos, categorias de preços etc. por cada tipo de produto. 
cíficos. De que maneira? Comunicando-lhe que o produto existe, ou anunciando.

Para as agências de publicidade é um período áureo em que o fabricante se prontifica a gastar. Contanto que tenha um bom filme de publicidade na TV Globo, dá-se por satisfeito, pois a Rede Globo vende. Para produzir um filme convincente (capaz até de tirar um prêmio em Cannes) é preciso pesquisar o mercado, ter um bom conhecimento sobre metodologias quantitativas e qualitativas na determinação da mídia, valorizar a criatividade e mesmo avançar até a fronteira onde o Marketing e a arte se encontram.

Curiosamente, a formula funcionou. Contanto que o fabricante tenha um produto atraente a oferecer (o que é provável numa economia em que a ânsia de consumo supera a capacidade de oferta das empresas), que a mensagem atinja o consumidor (o que também é provável num país onde todo mundo vê televisão) e que a agência saiba fazer um filme de qualidade (o que não é demasiadamente difícil junto a um público com poucas pretensões), a fórmula deve funcionar: a empresa vende, a agência fatura e ambos podem se dar ao luxo de pensar que estão praticando um Marketing perfeito.

Mas ainda não chegaram lá, pelo menos não para enfrentar e sobreviver num setor altamente competitivo. Para tal, será preciso estender a preocupação além do produto e de sua resistência tecnológica, e levar em conta também as preferências do consumidor em termos do grau de sofisticação, tamanho, gosto, leveza, ocupação de espaço, utilidade imediata e quaisquer outros aspectos que ajudem o produto a ser aceito pelo mercado. Isto requer do fabricante uma maior compenetração e dedicação aos problemas da aceitabilidade de seus produtos pelo comprador. Como ele faria isto?

\section{O CONSUMIDOR "PRECAVIDO"}

Implícito na tese de Aderson está a idéia de que Marketing só se pratica a partir do entrosamento entre as funções de "produto", "vendas" e "publicidade". Convém, no entanto, acrescentar uma quarta dimensão, que é o mercado. Mercado é a dimensão estratégica da oferta mercadológica dos bens e serviços. Ela requer observação e acompanhamento contínuo das forças que comandam a demanda para, em função da interpretação dos dados colhidos no ambiente, adaptar-se ao mercado bem como de preparar os insumos, tanto humanos quanto materiais, para que se tornem condizentes com os objetivos estratégicos da empresa. Normalmente, esta observação minuciosa do mercado conduz a uma constatação para muitos surpreendente: a demanda de um dado produto só raras vezes é homogênea. Ela se desdobra a partir de diferenciações de desejos, de idades, de origens, de estilos de vida dos consumidores e ao atender a estas diferenças, a empresa pode aumentar, por vezes consideravelmente, o volume de suas vendas, de seus lucros e retornos financeiros. Em outras palavras, convém segmentar o mercado.

Mas é difícil (ou nem vale a pena) esboçar uma estratégia racional frente a um mercado que sofre a instabilidade da moeda. Ao longo dos últimos anos, por mais que o consumidor tenha aprendido a se defender contra as agruras de uma economia descontrolada, pouco the adiantou o seu esforço: a inflação revelou-se mais forte. Ao longo do decênio $80 / 90$ transformou-se numa hiperinflação, admitam isto os economistas "oficiais" ou não: quando um nível de preços ascende de 40,8\% (em 78) para $2.567 \%$ (em 93) não há argumento que convença de que não haja hiperinflação. 


\section{Quadro 5: 0 cONSUMIDOR PRECAVIDO}

- Vive com orçamento apertado.

-É o consumidor que se sente "traído" pela crise, a inflação desenfreada, a perda de confiabilidade e de segurança.

- Surge e prolifera nas classes médias urbanas.

- Frustra-se, sente-se inseguro, irrita-se, revolta-se contra a "injustiça" de sua perda de poder aquisitivo.

- Culpa não só o governo e os "políticos" pela sua "desgraça", mas também quem não é geralmente responsável: o produtor e, sobretudo, 0 varejista (supermercado).

- Desconfia da mercadoria nas lojas, inspeciona mais, reclama, confere preços e pesos.

- Compra o mínimo por vez, procura evitar estoques - ou, ao contrário: estoca (freezer, adega) porque acha que compensa (quando tem os recursos).
- Perde a vergonha de "pechinchar" e busca constantes "vantagens" (descontos, remarcações, ofertas etc.) nos pontos de venda: * pesquisa preços de loja em loja;

* tornou-se mais ciente da saúde;

* compra quantidades menores por vezes:

* compra menos por impulso;

* escolhe marcas mais baratas.

- Sofre reflexos de suas tensões no trabalho e no lar, mas, procura, ao mesmo tempo, usar a "solidariedade" da família e do círculo social para se defender contra os impactos da crise (trabalho da mulher, troca de informações, compras conjuntas etc.).

- Acredita nos mecanismos de proteção ao consumidor (como o Procon) e reclama quando se sente prejudicado.

- Procura o entretenimento como meio de "escape" das pressões diárias, sobretudo quando jovem (música rock e heavy metah), ou "foge" do Brasil em viagens de turismo internacional (quando tem os recursos).

O público reclama, mas se acomoda como pode. Transforma o fenômeno inflacionário num bicho de estimação, um dinossauro pesado, mas manso, com quem se pode brincar. Com isto revela uma das características fundamentais do consumidor brasileiro: a capacidade de adaptar-se às condições, mesmo as mais adversas, sem perder o seu espírito esportivo. É a tolerância que chega ao extremo de se autocastigar, a elevação do jeito ao altar da veneração.

Aceitar o inevitável, no entanto, não significa aprová-lo. Por mais que procure escondê-lo, o consumidor de hoje é um cidadão decepcionado, desgostoso, com medo até de sua própria nação, a ponto de querer abandoná-la. Lá no fundo de sua alma permanece um foco de esperança, mas ele fica aceso apenas porque, de outra maneira, não seria possível sobreviver. Hoje, o consumidor utiliza a racionalidade adquirida em decênios anteriores para adotar uma política de extrema precaução. Planeja os seus gastos e só compra o essencial. Reclama e utiliza ao máximo os mecanismos de defesa que ele mesmo criou. Inspeciona mercadorias, pechincha e deixa de comprar quando não lhe agrada. Ao mesmo tempo, procura parceiros entre familiares e amigos para trocar idéias e informações, para comprar junto a granel, ou simplesmente para desabafar. É um consumidor reprimido e sofrido (ver quadro 5).

\section{MUDANÇAS ESTRUTURAIS INEVITÁVEIS}

Até os dados frios das nossas estatísticas refletem este sofrimento. É comum que, num país organizado, o consumo privado represente entre 70 a $75 \%$ do PIB. No período compreendido pelo nosso estudo, o Brasil movimentou-se ao longo desta média (até 61). A partir deste momento a curva, apesar de seus altos e baixos, apresentou uma ligeira tendência de queda (até 81), quando recuperou-se para chegar a $72 \%$ (em 83) e, a partir daí, caiu de maneira assustadora até $57 \%$ (em 89). Nos dois anos seguintes, recuperou-se, se bem que apenas ligeiramente. Ou seja: ao longo da "década perdida" de 1980 a 1990, a parcela do PIB destinada ao consumo perdeu $10 \%$ ou algo como US\$ 27 a US $\$ 30$ bilhões de dólares, o que corresponde mais ou menos ao dobro dos depósitos em poupança ocorridos no fim do período.

$E$ este o preço que o consumidor tem que pagar pela crise. Como houve um aumento na população ao longo dos dez anos, o sacrifício do consumo per capita ainda é maior: ele decresceu $16 \%$ durante o de- 


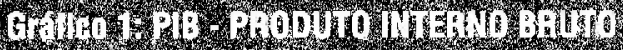

\section{$1956 / 1986$}

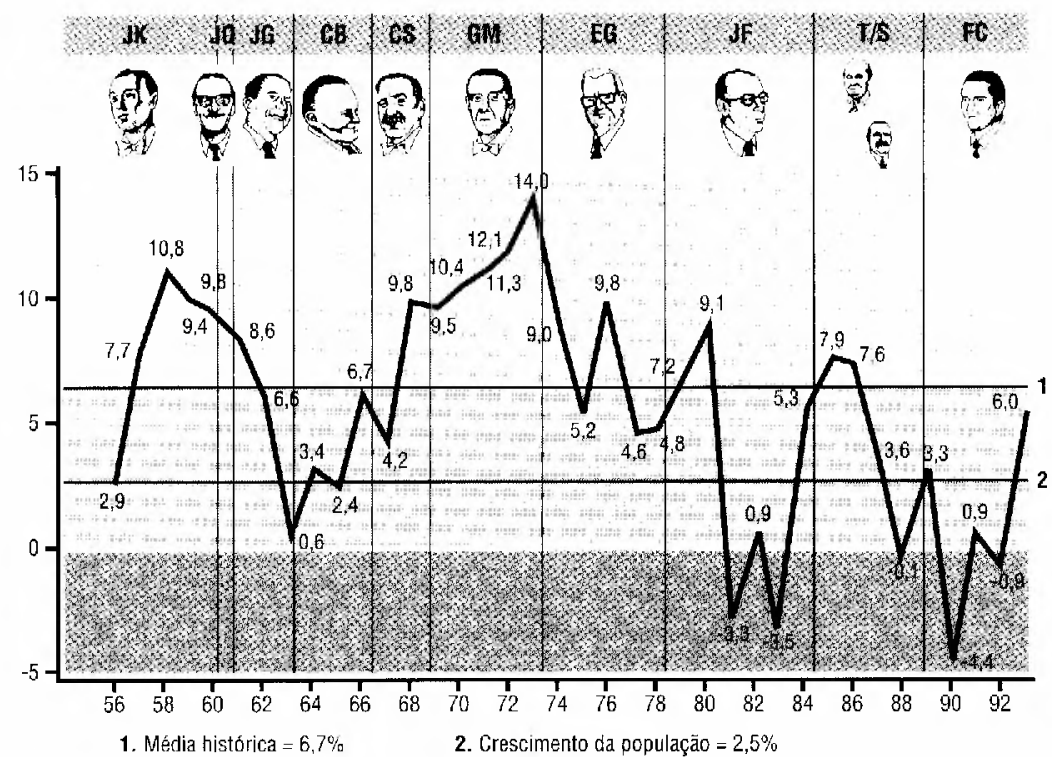

Fonte: FGV/BGE

cenio. Para onde foi o dinheiro? Na sua maior parte para o governo, pois os gastos públicos correntes ao longo dessa época elevaram-se de cerca de $9 \%$ para quase $16 \%$ em 1990 . São dispêndios e não investimentos, ou seja, o público foi sacrificado porque o seu governo esbanjou o que não era delc, $\mathrm{c}$ a probabilidade de que o dinheiro um dia seja devolvido é praticamente nula.

Como não poderia deixar de ser, a queda do consumo provocou uma mudança cstrutural na demanda de bens à qual a oferta se adaptou. Em termos relativos, aumentou o consumo dos itens básicos (alimentação, habitação, serviços públicos) de elasticidade-renda menor, cnquanto que os produtos duráveis e semi-duráveis sofreram uma queda, em parte até substancial.

\section{CONSIUERAÇOEES FINAIS}

E o futuro, o que trará? Isto dependerá mais das condições macroeconômicas e políticas do país do que das empresas, pois a maioria delas está preparada para deslanchar.

Enquanto perdurarem as condições de instabilidade econômica, a ênfase das empresas girará em torno da obtenção de lucros a curto prazo, seja através de uma política agressiva de preços elevados, seja por meio de aplicaçōes no mercado financeiro. Investimentos de vulto não acontecerão, mas sim melhoria de produtos numa escala mínima. A ordem é aguardar a ação governamental e o combate à inflação, mantendo as atividades da empresa "em banho-maria". O principal prejudicado será o consumidor. Ele terá que arcar com preços elevados e em constante ascensão para receber produtos de qualidade questionável. Ele continuará a lutar pelos seus direitos, mas será apenas medianamente bem-sucedido. $O$ que lhe desfavorece é a falta de concorrência entre as empresas, que operam num mercado frouxo, frente a um poder aquisitivo em queda. 
Mas há claros sinais de mudança de atitudes: um cansaço com a inércia da recessão inflacionária, a conscientização de que é preciso mudar até culturalmente - para que o país volte a crescer, a pressão dos jovens empreendedores, muitos desempregados, ansiosos em mostrar que têm condições de levar uma pequena empresa ao sucesso. O Governo precisa responder a esses anseios, enquanto a população precisa eleger um congresso razoavelmente bem-intencionado e dedicado às questões do país, assim, o Brasil deslanchará, e com ele, as empresas, e dentro das empresas, o Marketing.

Neste caso, uma nova época terá o seu início: será a época das empresas descentralizadas, informatizadas, bem menos hierárquicas e essencialmente voltadas ao serviço. Mais importante do que o seu tamanho será a administração do seu tempo: fazer com que as informações e os produtos fluam com rapidez e eficácia das fábricas, através de um mínimo de intermediários, às mãos do consumidor, pré-escolhido e conhecido pelos seus fornecedores nominalmente e quanto às suas preferências pessoais. $O$ Marketing entrará numa associação íntima com a área de informática que lhe fornecerá os insumos para poder realizar seus objetivos: colher informações do mercado, processá-las, classificá-las, preparar e dirigir mensagens certas a compradores certos, usando os caminhos mais curtos à sua disposição para atingir seus alvos num tempo e custo mínimo.

A descentralização das unidades operacionais e o aumento da autonomia de cada unidade permitirá ações mais rápidas, adaptações mais adequadas aos mercados regionais, melhor aproveitamento dos potenciais de mercado, a interiorização progressiva, o uso crescente do marketing direto e do telemarketing, a terceirização e o aumento substancial das franquias controladas e assistidas por órgãos centrais, pouco importa onde estejam localizadas.

Todos nós - respectivamente nossos filhos e netos - faremos parte de vários bancos de dados onde constarão não só o nosso nome e endereço, como também as nossas compras passadas, o nosso estilo de vida, as nossas preferências por categorias e até marcas de produtos. Estaremos, cada um de nós, ligados a uma imensa rede de comunicações, através do telefone móvel, do fax, do CD-ROM e de um sistema interativo de informações, não só escritas, como também visuais e auditivas. Isto nos permitirá manter contatos com pessoas e instituições conhecidas e desconhecidas à distância, solicitar e dar informações, debater assuntos de nosso interesse, ouvir e proferir palestras de nossas casas, interferir diretamente em programas televisionados, solicitar produtos e serviços e até, quem sabe, estabelecer contatos físicos com nossos interlocutores. Ao Marketing caberá então a função de coordenar e interligar todas estas atividades em favor de produtores e intermediários.

Tudo isto, evidentemente, não acontecerá da noite para o dia. Para alguns setores levará alguns anos, para outros, alguns decênios. E o ritmo da evolução não será comandado pela rapidez da inovação tecnológica, pois esta recebemos do exterior. Ela será antes uma função de nosso amadurecimento como nação que, ciente da sua responsabilidade social, prontifica-se a mudar o seu sistema de valores para poder integrarse no conjunto dos países avançados. Assim, o Marketing do futuro depende da reforma moral - quanto mais cedo esta mudar, tanto mais rápido e intenso será o nosso desenvolvimento. 